AGRICULTURE AND BIOLOGY JOURNAL OF NORTH AMERICA

ISSN Print: 2151-7517, ISSN Online: 2151-7525, doi:10.5251/abjna.2011.2.10.1340.1346

(C) 2011, ScienceHu $\beta$, http://www.scihub.org/ABJNA

\title{
Heterosis for litter size traits in native by two exotic inbred pig crosses
}

\author{
Nwakpu, P.E. and Onu, P.N.
}

\author{
Department of Animal Production and Fisheries Management, Ebonyi State \\ University, P.M.B 053 Abakaliki. Nigeria. E-mail: nnenwamazi@yahoo.com
}

\begin{abstract}
Inbred strains generated from native and exotic pigs were compared with their $F_{1}$ and $f_{2}$ backcross populations for a range of litter size performance traits. Animals were intensively reared and at $81 / 2$ months of age, the inbred genotypes from each strain were reciprocally mated to each other to generate $F_{1}$ crossbred genotypes; while gilts from each crossbred group were backcrossed to their male parents to obtain four backcross progeny groups. Litter size traits performances were better in the crossbred groups than in the inbred parents and this improvement could be ascribed to the dominant genes from the exotic parents. Significant $(P<0.05)$ heterosis were obtained by the crossbred groups in most of the litter size characteristics like prolificacy, nursing ability, sex ratio, litter weight and gestation lengths. The heterosis observed in the litter size traits were low and mostly non - significant. The backcross groups recorded residual heterosis in the litter size traits monitored and the magnitude was higher in the exotic than the native backcrosses. The results future indicate that the litter size traits performance of the crossbred groups were mostly influenced by maternal, sex -linked, dominance and epistatic gene actions. It could be suggested that the litter size traits production potential of the native pig could be improved further by cross mating selected native and exotic backcross pig. This could be followed by crises - crossing before group trait selection.
\end{abstract}

\begin{abstract}
Keywords: - Crosses, genotypes, heterosis, in INTRODUCTION

In Nigeria, government's policy on the ban of importation of inputs and services in the livestock sub - sector have further exacerbated the plight of farmers in sourcing breeds of livestock especially pigs. What is found any where in Nigeria today are basically several cross bred generations abandoned here by the expertrates in the late " $70^{\mathrm{s}}$. Nwosu ${ }^{[6]}$ in his emphasis on how to form a formidable foundation for our monogastric farming in Nigeria, had harped on the need to involve the native pig or poultry as part of our seed stock development. Adebambo ${ }^{[1]}$ Olomu and Oboh ${ }^{[9]}$ and Williamson and Payne ${ }^{[13]}$ had all maintained that though, our Native pigs are noted to perform poorly in growth, they possess useful genetic attributes like tolerance to harsh weather and poor diets, diseases and parasites, good maternal qualities and nick ability when crossed with the exotic breeds.
\end{abstract}

These are desirable genetic attributes that can be harnessed during crossbreeding for development of higher litter size and reproductive traits among our native pig genotypes before they become extinct. Our native pig according to Marire et al., ${ }^{[5]}$ are noted to compare favourably in growth characteristics with their exotic counterparts and has the singular ability
, litter size, strains and traits.

to transmit genes for early age at sexual maturity, good maternal ability, most probable producing ability (MPPA) and produces high heterotic levels in harsh conditions when crossed with the exotic breeds. Female reproductive traits have low to moderate heritability. The most heritable traits are those depending solely on the genotype of the female i.e. age at puberty, ovulation rate and weaning to estrus interval.

Conversely, litter size, conception and survival rates and to a lesser extent, litter weight, which result from complex interactions between sow, boar and embryo or piglet genotypes have low heritability is therefore difficult to improve through selection. Pig producers have long known that crossbreeding is an effective means of improving reproduction performance. This improvement called heterosis or hybrid vigour, comes from an increase in heterozygosity, which leads to better average genotypic values at dominant loci. As already mentioned, litter traits are controlled by the genes of both piglets and sows and enhanced performance may come from crossed piglets (i.e. direct or individual heterosis effect) or crossed dams (i.e. sow or maternal heterosis effects). Litter heterosis effects lead to slightly larger litter size at birth and to higher piglet survival and litter weights. 
This is why a study to evaluate the heterosis for litter size traits in the $F_{1}$ and the residual heterosis in the backcrosses of the native and two exotic pigs using a crossbreeding strategy known as the back and criss - cross heterosis evaluation technique (BAC CET)designed by Omeje ${ }^{[8]}$ is being investigated.

\section{MATERIALS AND METHODS}

Experimental Animals: This comprised inbred strains generated from the within strain mating of two exotic breeds of pigs (Large White and Landrace) and the Nigerian native pig established and maintained at the Piggery Breeding and Research unit of Ebonyi State University, Abakaliki, Ebonyi State, Nigeria .The study was reviewed and approved by Ebonyi State University animal care and use committee.

Fig. 1: - The crossbreeding strategy (BAC - CET) involving the inbred native by exotic inbred crosses'.

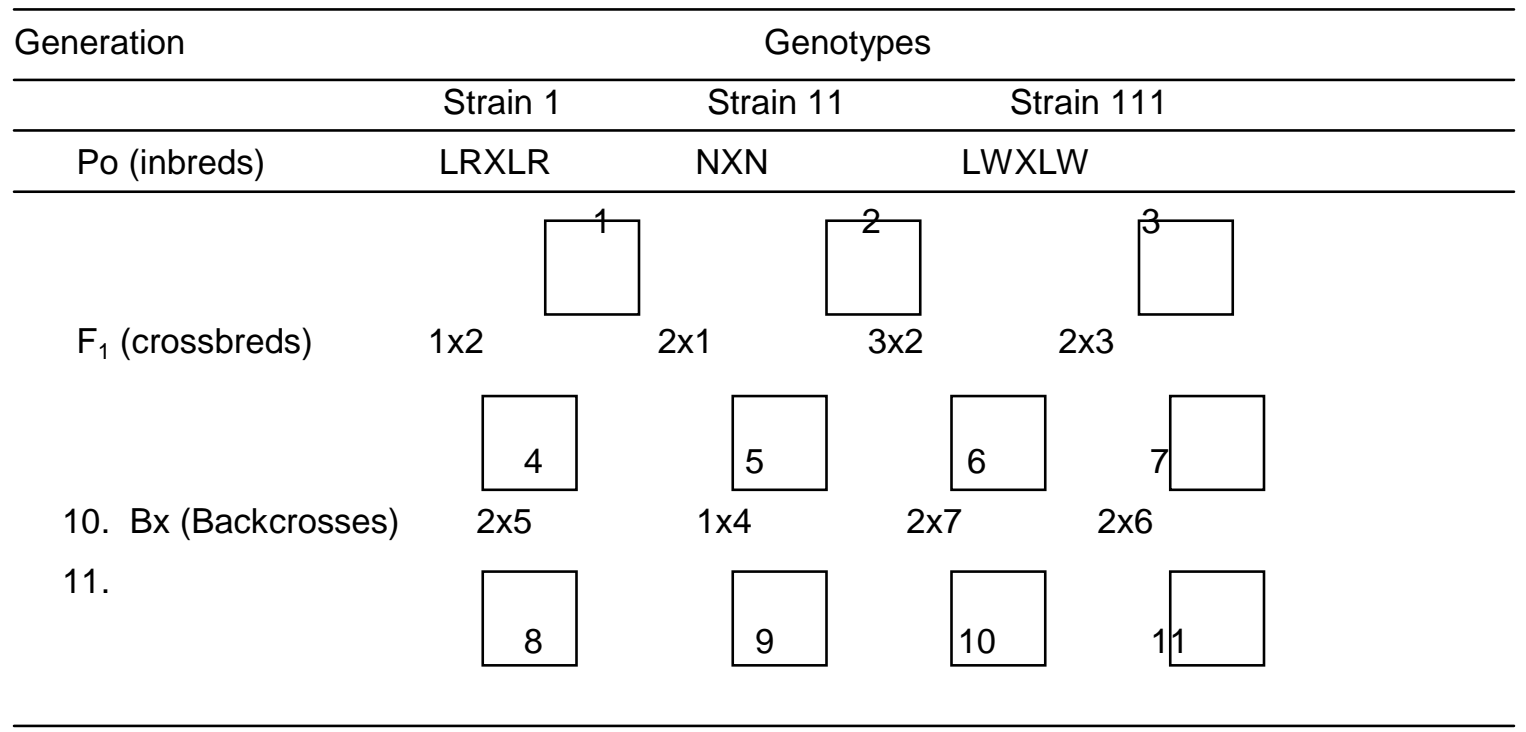

12. Po: -Base population

NxN: - Native; LRxLR - landrace; LWxLW - Large White breeds. $F_{1}$ - First filial generation (Crossbreds), $\mathrm{B}_{\mathrm{X}}$ - Backcross generation (Second Filial generation). Adapted from Omeje, (1989).

Management of the Animals: The animals were intensively reared in standard pens according to their litter groups. Piglets were brooded and fed ad libitum for eight weeks with a pig starter diet which on analysis showed $22 \%$ crude protein and $2900 \mathrm{kcal}$ $\mathrm{ME} / \mathrm{kg}$. From two to eight months, they were fed growers mash containing $2750 \mathrm{kcal} \mathrm{ME} / \mathrm{kg}$ and $17 \%$ crude protein while breeders' mash containing $2850 \mathrm{kcal} \mathrm{ME} / \mathrm{kg}$ and $20 \%$ crude protein was provided as from 8 months to 18 months of age. Water for drinking was provided ad - libitum throughout the period. The animals were dewormed on routine basis and other therapeutic treatments provided as the
Mating Arrangement: at $8 \frac{1}{2}$ months of age, inbred genotypes from each strain $\mathrm{N} \times \mathrm{N}, \mathrm{LW} \times \mathrm{LW}$ and $\mathrm{LR} \times$ LR representing native, Large White and Landrace inbreds respectively were reciprocally mated to each other to generate $F_{1}$ crossbred populations. The mating arrangement which is a part of the BAC CET design already mentioned is shown in figure 1. Similarly, at $8 \frac{1}{2}$ months of age, gilts from each crossbred group were backcrossed to the male parents to obtain four backcross progeny genotypes or groups as shown in Figure 1 above. Artificial insemination was the system adopted in mating of the gilts by the sows to forestall the problems of size differences associated with hand mating. 
$\mathrm{u}=$ population means.

$g i=$ Effect of $i^{\text {th }}$ strain on the traits (e.g. litter size, litter weight, sex - ratio etc)

tij =Random variable (e.g. litter size) due to the effect of the $\mathrm{j}^{\text {th }}$ strain within and between them.

eijk $=k^{\text {th }}$ error or individual piglet difference.

For the $\mathrm{F}_{1}$ crossbred and the backcrosses data were also analysed by means of one-way analysis of variance in a completely randomized design (Weiner, ${ }^{[12]}$ with the various breeding groups as main source of variation. Duncan's multiple range test was used to compare means for differences.

Estimation of Heterosis: - Heterosis among the $F_{1}$ piglets were estimated as the mean crossbred deviation expressed in percentage of mid - parent performance. Backcross heterosis was computed from the average additive merit

$\mathrm{E}(\mathrm{Bx})$ expected of each backcross as outlined by Omeje and Nwosu ${ }^{[8]}$.

$E\left(B x_{1}\right)=P+1 / 2\left[P_{1}-P\right]$ for a backcross to $P_{1}$ parent.

$E\left(B x_{2}\right)=P+1 / 2\left[P_{2}-P\right]$ for a backcross to $P_{2}$ parent

Heterosis $=\mathrm{Bx}_{1}-\mathrm{E}\left(\mathrm{Bx}_{1}\right)=$ Heterosis by the $\mathrm{Bx}_{1}$ backcross.

$\mathrm{Bx}_{2}-\mathrm{E}\left(\mathrm{Bx}_{2}\right)=$ Heterosis by the $\mathrm{Bx}_{2}$ backcross.

A simple $t$ - test was used to compare the cross bred data with their mid - parent for significance of heterotic performance using procedures outlined by Yule and Kendall ${ }^{[14]}$

Genetic Analysis of Heterosis: The heterosis obtained from the backcross groups were respectively compared with the $F_{1}$ heterosis by expressing the mean heterosis of the backcross group as a percentage of $F_{1}$. The results of the backcross heterosis relative to $F_{1}$ were fitted against the complete dominance and parental epistasis model postulated by Sheridan ${ }^{[10]}$.

\section{RESULTS}

In this model, Table1, the $F_{1}$ heterosis relative to itself is $100 \%$ whether it is complete dominance or epistatic gene action that is operating. The relative performance of the backcross group was compared with the Figure expected of the family or mating arrangement under any of the gene actions. If a particular result was of the same or nearly the same magnitude with the corresponding predicted value in this model, then it will be taken that the experimental data fitted well into the particular model of gene action responsible for heterosis.

Table 2 shows the litter traits characteristics of inbred native and two exotic inbred pig genotypes used for the cross breeding. Significant differences $(P<0.05)$ were observed among the inbred genotypes in all the traits, except for gestation length and sex - ratio. The landrace and large white were superior to the native counterparts in most of the traits.

Table 1:- Comparison of percentage heterosis expected under various mating schemes for the dominance and parental epistasis models with complimentary loci (Sheridan, 1981)

\begin{tabular}{|l|l|l|l|}
\hline Mating & Dominance & Parental & Epistasis \\
\hline Schemes & hypothesis & 2 loci & 3 loci. \\
\hline Purebred & 0.00 & 0.00 & 0.00 \\
\hline $\mathrm{F}_{1}$ & 100.00 & 100.00 & 100.00 \\
\hline $\begin{array}{l}\mathrm{F}_{2} \text { (two breed } \\
\text { synthetic) }\end{array}$ & 50.00 & 12.50 & -15.60 \\
\hline Backcross & 50.00 & 25.00 & 12.50 \\
\hline $\begin{array}{l}\text { Three way } \\
\text { cross }\end{array}$ & 100.00 & 50.00 & 25.00 \\
\hline $\begin{array}{l}\text { Four way } \\
\text { cross }\end{array}$ & 100.00 & 0.00 & -50.00 \\
\hline $\begin{array}{l}\text { Rotational } \\
\text { cross (2 } \\
\text { breeds) }\end{array}$ & 66.70 & 44.40 & 29.60 \\
\hline $\begin{array}{l}\text { Rotational } \\
\text { cross (3 } \\
\text { breeds) }\end{array}$ & 85.70 & 40.80 & 21.00 \\
\hline
\end{tabular}

The percentage values are relative to $F_{1}$.

Table 2:- Means +-S.E for litter size traits of the inbred genotypes belonging to the native and two exotic pig strains.

\begin{tabular}{|l|l|l|l|}
\hline Traits & \multicolumn{3}{|l|}{ Strains } \\
\hline & LRxLR & NxN & LWxLW \\
\hline & $\mathrm{I}$ & $\mathrm{II}$ & $\mathrm{III}$ \\
\hline $\begin{array}{l}\text { Litter Sex at } \\
\text { birth }\end{array}$ & $8.50^{\mathrm{a}}$ & $6.50^{\mathrm{c}}$ & $7.50^{\mathrm{b}}$ \\
\hline & $(0.05)$ & $(0.02)$ & $(0.30)$ \\
\hline $\begin{array}{l}\text { Litter Sex at } \\
\text { weaning }\end{array}$ & $7.50^{\mathrm{a}}$ & $5.50^{\mathrm{c}}$ & $6.50^{\mathrm{b}}$ \\
\hline & $(0.21)$ & $(0.15)$ & $(6.50)$ \\
\hline Age at puberty & 267 & 245 & 262 \\
\hline $\begin{array}{l}\text { Litter weight at } \\
\text { birth }\end{array}$ & $(2.0)$ & $(3.0)$ & $(2.1)$ \\
\hline & $(0.20)$ & $0.85^{\mathrm{b}}$ & $1.50^{\mathrm{a}}$ \\
\hline $\begin{array}{l}\text { Litter weight at } \\
\text { weaning }\end{array}$ & $27.00^{\mathrm{a}}$ & $18.15)$ & $(0.25)$ \\
\hline $\begin{array}{l}\text { Gestation } \\
\text { length }\end{array}$ & 118 & 111 & $24.10^{\mathrm{a}}$ \\
\hline & $(2.0)$ & $(1.0)$ & 122 \\
\hline $\begin{array}{l}\text { Sex - ratio at } \\
\text { birth }\end{array}$ & 1.25 & 0.85 & 1.10 \\
\hline & $(0.25)$ & $(0.15)$ & $(0.15)$ \\
\hline $\begin{array}{l}\text { Sex - ratio at } \\
\text { weaning }\end{array}$ & 1.05 & 0.65 & 1.00 \\
\hline & $(0.02)$ & $(0.05)$ & $(0.01)$ \\
\hline
\end{tabular}

a, b, c: - For each trait and within each strain, means superscripted with different letters

are significantly different $(P<0.05)$

Note: Standard errors are in parentheses. 
Agric. Biol. J. N. Am., 2011, 2(10): 1340-1346

The Landrace genotypes were superior to the large white in their litter size at birth and at weaning. Whereas, the two inbred exotic genotypes did not differ $(P>0.05)$ in age at puberty which was longer than the native genotypes. Litter weight at birth was higher in the large white than the landrace. The litter size traits characteristics of the $F_{1}$ crossbred and the backcross groups are presented in Table 3 and 4 respectively.

Litter size at birth was higher among the crossbred groups when compared with their parental averages (Table 2). The only exceptions being the main crossbreds involving the Large White and Native (LW $x \mathrm{~N})$. Whose litter size at birth (6.00 piglets) were less than their native (6.50 piglets) parents. The litter size at birth of the backcrosses were similar to the $F_{1}$ mean values in most of the groups (Table 4). However, the reciprocal backcross involving the $(\mathrm{N} \mathrm{x}$ $L W) \times N$ also did not differ from the $F_{1}$ main crossbred LW x N.

Table 3:- Means +-S.E for litter size traits characteristic of the $F_{1}$ crossbred group.

\begin{tabular}{|l|l|l|l|l|}
\hline Traits & \multicolumn{4}{|c|}{ Strains } \\
\hline & LRxN & NxLR & LWxN & NxLW \\
\hline & $\mathrm{I}$ & $\mathrm{I}$ & $\mathrm{II}$ & $\mathrm{IV}$ \\
\hline Litter Size at birth & $10.00^{\mathrm{a}}$ & $8.00^{\mathrm{b}}$ & $6.00^{\mathrm{c}}$ & $6.50^{\mathrm{c}}$ \\
\hline & $(0.60)$ & $(0.60)$ & $(0.60)$ & $(0.50)$ \\
\hline Litter size at weaning & $5.50^{\mathrm{b}}$ & $7.50^{\mathrm{a}}$ & $5.00^{\mathrm{b}}$ & $4.00^{\mathrm{b}}$ \\
\hline & $(0.50)$ & $(0.51)$ & $(0.10)$ & $(0.10)$ \\
\hline Age at puberty & 255 & 258 & 250 & 254 \\
\hline & $(1.20)$ & $(2.00)$ & $(2.00)$ & $(1.80)$ \\
\hline Litter weight at birth & 1.80 & 1.17 & 1.10 & 1.30 \\
\hline & $(0.03)$ & $(0.02)$ & $(0.10)$ & $(0.10)$ \\
\hline $\begin{array}{l}\text { Litter weight } \\
\text { weaning }\end{array}$ & 19.05 & 19.99 & 18.54 & 17.39 \\
\hline & $(1.55)$ & $(1.29)$ & $(1.46)$ & $(1.29)$ \\
\hline Gestation length & $122^{\mathrm{a}}$ & $117^{\mathrm{b}}$ & $1175^{\mathrm{b}}$ & $123^{\mathrm{a}}$ \\
\hline & $(2.0)$ & $(2.50)$ & $(2.50)$ & $(2.00)$ \\
\hline Sex - ratio at birth & 0.69 & 0.78 & 0.71 & 0.63 \\
\hline & $(0.12)$ & $(0.03)$ & $(0.04)$ & $(0.13)$ \\
\hline $\begin{array}{l}\text { Sex - ratio } \\
\text { weaning }\end{array}$ & 0.59 & 0.65 & 0.67 & 0.59 \\
\hline & $(0.09)$ & $(0.15)$ & $(0.10)$ & $(0.09)$ \\
\hline $\begin{array}{l}\text { No of Pigs providing } \\
\text { data }\end{array}$ & 128 & 122 & 120 & 121 \\
\hline
\end{tabular}

$a, b, c$ : - Means for each trait and strain not followed by same superscript are statistically, $(\mathrm{P}<0.05)$ different.

Note: standard errors are in parenthesis,

$\mathrm{LR} \times \mathrm{N}=$ Landrace $\times$ Native (Main crossbred).

$\mathrm{N} \times \mathrm{LR}=$ Native $\times$ Landrace (Reciprocal crossbred)

LW $\times \mathrm{N}=$ Largewhite $\times$ Native (Backcross)

$\mathrm{N} \times \mathrm{LW}=$ Native $\times$ Large White $\times$ Native (Reciprocal crossbred)
Table 4:- Means +-S.E for litter size traits of the Backcross progeny groups.

\begin{tabular}{|c|c|c|c|c|}
\hline \multicolumn{5}{|c|}{ Strains } \\
\hline Traits & $\begin{array}{l}\text { (LRxN } \\
\text { ) } x \text { LR }\end{array}$ & $\begin{array}{l}(\mathrm{NxLR}) \mathrm{x} \\
\mathrm{N}\end{array}$ & $\begin{array}{l}(\mathrm{LW} \times \mathrm{N}) \mathrm{x} \\
\mathrm{LW}\end{array}$ & $\begin{array}{l}(\mathrm{NxLW}) \mathrm{x} \\
\mathrm{N}\end{array}$ \\
\hline & $\mathrm{I}$ & II & III & IV \\
\hline \multirow[t]{2}{*}{ Litter size at birth } & $8.50^{c}$ & $6.50^{\mathrm{a}}$ & $7.50^{b}$ & $6.00^{\mathrm{a}}$ \\
\hline & $(0.86)$ & $(0.80)$ & $(0.80)$ & $(0.40)$ \\
\hline \multirow[t]{2}{*}{$\begin{array}{l}\text { Litter size at } \\
\text { weaning }\end{array}$} & $4.50^{a}$ & $4.00^{a}$ & $7.50^{c}$ & $6.00^{b}$ \\
\hline & $(0.50)$ & $(0.80)$ & $(0.80)$ & $(0.20)$ \\
\hline \multirow[t]{2}{*}{ Age at Puberty } & 240 & 250 & 230 & 235 \\
\hline & $(1.60)$ & (2.0) & $(2.10)$ & $(2.50)$ \\
\hline \multirow[t]{2}{*}{$\begin{array}{l}\text { Litter weight at } \\
\text { birth }\end{array}$} & 1.05 & 1.15 & 1.25 & 1.20 \\
\hline & $(0.05)$ & $(0.06)$ & $(0.07)$ & $(0.10)$ \\
\hline \multirow[t]{2}{*}{$\begin{array}{l}\text { Litter weight at } \\
\text { weaning }\end{array}$} & 18.02 & 15.75 & 17.40 & 17.70 \\
\hline & $(1.42)$ & $(1.55)$ & $(1.20)$ & $(1.30)$ \\
\hline \multirow[t]{2}{*}{ Gestation length } & 121.50 & $118.00^{\mathrm{a}}$ & $118.00^{\mathrm{a}}$ & $122.00^{b}$ \\
\hline & $(2.50)$ & $(2.00)$ & $(2.00)$ & $(2.50)$ \\
\hline \multirow[t]{2}{*}{ Sex - ratio at birth } & 0.70 & 0.64 & 0.68 & 0.50 \\
\hline & $(0.10)$ & $(0.14)$ & $(0.18)$ & $(0.21)$ \\
\hline \multirow[t]{2}{*}{$\begin{array}{l}\text { Sex - ratio at } \\
\text { weaning }\end{array}$} & 0.84 & 0.59 & 0.68 & 0.46 \\
\hline & $(0.16)$ & $(0.19)$ & $(0.18)$ & $(0.21)$ \\
\hline $\begin{array}{l}\text { Number } \\
\text { Animals }\end{array}$ & 124 & 118 & 211 & 231 \\
\hline
\end{tabular}

a, b, c: - Mean values along the same row with different superscripts are. significantly different $(P<0.05)$.

Note: - Standard errors are in parenthesis.

Table 5:- Heterosis of litter size traits among $F^{1}$ Crossbred groups ${ }^{1}$.

\begin{tabular}{|l|l|l|l|l|}
\hline \multicolumn{5}{|c|}{ Strains } \\
\hline Traits & LR x N & N x LR & LW x N & N x LW \\
\hline & $\mathbf{I}$ & II & III & IV \\
\hline $\begin{array}{l}\text { Litter size at } \\
\text { birth }\end{array}$ & $48.50^{* *}$ & $52.96^{* *}$ & $50.69^{* *}$ & $62.52^{* *}$ \\
\hline & $(3.10)$ & $(2.36)$ & $(2.86)$ & $(2.29)$ \\
\hline $\begin{array}{l}\text { Litter size at } \\
\text { weaning }\end{array}$ & $43.60^{* *}$ & $48.67^{* *}$ & $46.40^{* *}$ & $53.60^{* *}$ \\
\hline $\begin{array}{l}\text { Litter weight } \\
\text { at birth }\end{array}$ & $(2.50)$ & $(2.30)$ & $(2.20)$ & $(2.41)$ \\
\hline & $(0.17)$ & $(0.51)$ & $(0.38)$ & $(0.56)$ \\
\hline $\begin{array}{l}\text { Litter weight } \\
\text { at weaning }\end{array}$ & $1.42^{N S}$ & $1.15^{\text {NS }}$ & $1.21^{N S}$ & $1.31^{N S}$ \\
\hline & $(0.03)$ & $(0.06)$ & $(0.02)$ & $(0.06)$ \\
\hline $\begin{array}{l}\text { Gestation } \\
\text { length }\end{array}$ & $16.56^{*}$ & $12.43^{*}$ & $15.50^{*}$ & $13.10^{*}$ \\
\hline & $(1.42)$ & $(1.01)$ & $(0.95)$ & $(1.15)$ \\
\hline
\end{tabular}

Note: - Standard errors are in parenthesis.

${ }^{*} \mathrm{P}<0.05$, NS:- Not significant $(P>0.05),{ }^{*} \mathrm{P}<0.01$. 
Agric. Biol. J. N. Am., 2011, 2(10): 1340-1346

Table 6:- Mean \pm S.E for heterosis in litter size traits of the backcross progeny groups ${ }^{1}$.

\begin{tabular}{|c|c|c|c|c|}
\hline \multicolumn{5}{|c|}{ Strains } \\
\hline Traits & $(\mathrm{LR} \times \mathrm{N}) \times \mathrm{LR}$ & $(\mathrm{NxLR}) \times \mathrm{N}$ & $(\mathrm{LW} \times \mathrm{N}) \times \mathrm{LW}$ & $(\mathrm{NxLW}) \times \mathrm{N}$ \\
\hline & I & II & III & IV \\
\hline \multirow[t]{2}{*}{ Litter size at birth } & $19.29^{\star \star}$ & $21.12^{\star \star}$ & $21.45^{\star \star}$ & $23.07^{\star *}$ \\
\hline & $(1.67)$ & $(1.19)$ & $(1.67)$ & $(1.19)$ \\
\hline \multirow{2}{*}{ Litter size at weaning } & $13.30^{* *}$ & $14.70^{* *}$ & $15.60^{*}$ & $17.35^{\star *}$ \\
\hline & $(1.34)$ & $(1.43)$ & $(1.23)$ & $(1.48)$ \\
\hline \multirow[t]{2}{*}{ Litter weight at birth } & $-0.38^{\text {NS }}$ & $-0.80^{\text {NS }}$ & $-1.20^{\text {NS }}$ & $-1.32^{\text {NS }}$ \\
\hline & $(0.15)$ & $(0.20)$ & $(0.40)$ & $(0.35)$ \\
\hline \multirow[t]{2}{*}{ Litter weight at weaning } & $-0.92^{\text {NS }}$ & $-0.99^{\text {NS }}$ & $1.42^{*}$ & $2.03^{\star *}$ \\
\hline & $(0.40)$ & $(0.52)$ & $(0.30)$ & $(0.92)$ \\
\hline \multirow[t]{2}{*}{ Gestation length } & $0.08^{N S}$ & $0.10^{\text {NS }}$ & $0.12^{*}$ & $0.15^{\star \star}$ \\
\hline & $(0.01)$ & $(0.02)$ & $(0.06)$ & $(0.04)$ \\
\hline
\end{tabular}

Note: - Standard errors are in parenthesis.

${ }^{*} \mathrm{P}<0.05$, NS:- Not significant $(P>0.05),{ }^{* *} \mathrm{P}<0.01$.

$1:$-Measured in actual deviation from the average additive merit $\mathrm{E}(\mathrm{Bx})$ expected of each backcross.

For litter size at weaning, the reciprocal crossbred $\mathrm{N}$ $x$ LR and main backcross ( LW $x \mathrm{~N}) \times \mathrm{LW}$ with an average of 7.50 piglets were the most superior, followed by their reciprocal backcross $(\mathrm{N} \times \mathrm{LW}) \times \mathrm{N}$ with 6.00 piglets and main crossbred LR $\times \mathrm{N}$ with 5.50 piglets. The least were from the reciprocal crossbred $\mathrm{N} \times \mathrm{LW}$ and backcross $(\mathrm{N} \times \mathrm{LR}) \times \mathrm{N}$ with 4.00 piglets each respectively. Results also shows significant differences $(\mathrm{P}<0.05)$ in the litter size at weaning involving $F_{1}$ native and landrace crossbreds to the crossbreds of native and Large White. The reverse is the case in the litter size at weaning involving the backcrosses where superior performance was obtained from the backcrosses involving native and Large White than that of native and Landrace. Lack of significant $(P>0.05)$ differences were observed in the age at puberty, gestation length and sex - ratio at birth and at weaning of the $F_{1}$ crossbred genotypes. However, significant differences $(P<0.05)$ was observed in the gestation length of the backcross genotypes with the main backcross $(L R \times N) \times L R$ and $(N \times L W) \times N$ having larger gestations (Table 4). The exotic crossbred genotypes were superior to their native counterparts in the litter weight at birth and weaning (Table 3) but did not portray any significant $(P>0.05)$ differences. In the same vein, the backcross genotypes did not show any significant $(P>0.05)$ differences in their litter weight at birth and at weaning (Table 4). Table 5 and 6 present the heterosis for litter size traits of the $F_{1}$ crossbred and the backcross groups respectively. The litter size at birth and at weaning heterotic performance of the $F_{1}$ crosses indicate that all the crossbred and backcross groups recorded highly significant $(P<0.05)$ effect on litter size traits (Table5 and 6).

The results showed that the highest heterosis in litter size at birth and at weaning was obtained from the reciprocal crossbreds and backcrosses with $62.52 \%$ and $23.07 \%$ for litter size at birth and $53.60 \%$ and $17.35 \%$ for litter size at weaning respectively. The $F_{1}$ crossbred groups recorded non - significant $(P>0.05)$ heteroses in litter weight at birth and at weaning (Table 5), whereas, litter weight heteroses for the backcrosses were mostly negative and non significant. The negative heterosis implies that the crossbred performance was less than the mid parent average in litter weight at birth and at weaning. A similar trend was observed for the backcross heterosis in litter weight (Table 6) except for the reciprocal backcross $(\mathrm{N} \times \mathrm{LW}) \times \mathrm{N}$ which shared highly significant $(\mathrm{P}<0.05)$ heterosis of $2.03 \%$. The reciprocal crossbred and backcross groups registered higher heteroses in both traits compared with the main crossbred and main backcross groups. Heterotic performance for gestation length was significant $(P<0.05)$ and positive for the $F_{1}$ crossbred group but non - significant for the backcross groups except reciprocal backcross $(\mathrm{N} \times \mathrm{LW}) \times \mathrm{N}$ that had highly significant improvement. The main crossbred genotype LR $\times \mathrm{N}$ showed the highest heterosis in gestation length with $16.56 \%$. Table 7 is a summary of the backcross heterosis in litter size traits expressed as a percentage of the $F_{1}$ to ascertain the mode of gene action responsible for heterosis. 
Agric. Biol. J. N. Am., 2011, 2(10): 1340-1346

Table 7: summary of the backcross heterosis in litter size traits expressed as a percentage of the $F_{1}$ to ascertain the mode of gene action responsible for heterosis

\begin{tabular}{|c|c|c|c|c|c|}
\hline & Litter size & Litter size & Litter weight & $\begin{array}{c}\text { Litter } \\
\text { weight }\end{array}$ & $\begin{array}{c}\text { Gestation } \\
\text { length }\end{array}$ \\
\hline & at birth & at weaning & at birth & $\begin{array}{c}\text { at } \\
\text { weaning }\end{array}$ & \\
\hline Mating & $\begin{array}{c}\text { complete } \\
\text { parental }\end{array}$ & $\begin{array}{l}\text { complete } \\
\text { parental }\end{array}$ & complete parental & $\begin{array}{l}\text { complete } \\
\text { parental }\end{array}$ & complete parental \\
\hline Scheme & $\begin{array}{c}\text { dominance } \\
\text { epitasis }\end{array}$ & $\begin{array}{c}\text { dominance } \\
\text { epitasis }\end{array}$ & dominance epitasis & $\begin{array}{c}\text { dominance } \\
\text { epitasis }\end{array}$ & $\begin{array}{c}\text { dominance } \\
\text { epitasis }\end{array}$ \\
\hline & (2loci) & (2loci) & (2loci) & (2loci) & (2loci) \\
\hline \multicolumn{6}{|l|}{ Type of cross } \\
\hline F1 cross & $\begin{array}{l}100 \\
100 \\
\end{array}$ & 100 & 100 & 100 & 100 \\
\hline \multicolumn{6}{|l|}{ Back crosses } \\
\hline$(\mathrm{LRxN}) \times \mathrm{LR}$ & 11.82 & 13.10 & 10.05 & -18.20 & -18.16 \\
\hline$(\mathrm{N} x \mathrm{LR}) \times \mathrm{N}$ & -19.15 & -18.40 & 3.19 & 10.18 & -14.50 \\
\hline$(\mathrm{LW} \times \mathrm{N}) \times \mathrm{LW}$ & 10.14 & 11.32 & -18.50 & -16.50 & 14.40 \\
\hline$(\mathrm{NxLW}) \mathrm{xN}$ & -18.63 & -16.36 & -19.50 & 17.17 & 10.49 \\
\hline
\end{tabular}

\section{DISCUSSION}

The significant differences observed among the inbred lines of each exotic strain in some of these traits (Table 2) categorized them as distinct groups, each will contribute to the improvement of the native pig. Among the $F_{1}$ crossbred groups, significant differences $(P<0.05)$ were observed in most of the traits measured. The data obtained by the crossbred groups indicate that while sire influenced the litter size at birth and at weaning, non - additive genetic effects were responsible for the inheritance of the trait in the other crossbred groups. Gunset and Robinson, ${ }^{[3]}$ had earlier observed that sire influence as well as additive effects were important in the inheritance of prolificacy and better nursing ability of the crossbred genotypes. They posited that, crossbred females have $2-4 \%$ higher conception rates, slightly larger ovulation rates (+0.5 ova) and 0.6 to 0.7 more piglets at weaning. Post farrowing survival of piglets is higher for crossbred sows (5\%) and litter weights are greater $(+1 \mathrm{~kg}$ at birth and $+4.2 \mathrm{~kg}$ at 21days). Litter heterosis effects lead to slightly larger litter size at birth (+0.24 piglet per litter) and to a higher piglet survival $(+5.8 \%)$ and litter weights. Also, in terms of sow heterosis, there is an average reduction in age at puberty of 11.3 days for crossbred sows. It should be noted that heterosis values might differ according to breed Combinations. For instance, Large White and Landrace crosses generally exhibit lower heterosis values than other crosses between European or American breeds. Haley et al., ${ }^{[4]}$ indicated that heterosis values in crosses between large white and Meishan breeds are higher than in two or threefold Large White and Landrace crosses. Bidanel, ${ }^{[2]}$ had noted that heterosis for age at puberty is around $40-50$ days and that sow heterosis effects on litter size at birth and at weaning exceed two piglets per litter. On gestation length and sex - ratio at birth and at weaning, the LRXN main crossbred and NXLW reciprocal crossbred showed longer gestation days as against other groups.

Similarly, the sex - ratio of the crossbred groups portrayed the reciprocal genotype NXLR as the most superior though not significant among the groups. The superiority of the reciprocal crossbred to others in sex - ratio trait can be linked to the native genome which have been adjudged by Olomu and Oboh ${ }^{[9]}$ as unique. The higher significant heterosis recorded by the $F_{1}$ crossbred in traits related to prolificacy, nursing ability, litter weight at birth and weaning of the reciprocal crossbreds over the maincrossbreds may be as a result of maternal impact of the dams acquired from the dominant genes of the exotic parents. The result of significant heterosis observed among the $F_{1}$ crossbreds is consistent with the reports of Bidanel ${ }^{[2]}$. This indicates that significant improvement in these traits can be achieved by the reciprocal mating of the native and exotic pigs. The higher heterosis recorded by the reciprocal cross groups over their maincross groups implies that, maternal influence was more important than sex linkage effect in the reproductive traits of pig. Earlier studies by Nwakpu and Omeje ${ }^{[7]}$ had reported 
Agric. Biol. J. N. Am., 2011, 2(10): 1340-1346

positive and significant heteroses in the reciprocal crossbred but not on the maincrossbred. The researchers inferred that crossing the exotic boar with native sow would yield rapid improvement especially when the parents of the crossbreds are confined. The $F_{1}$ crossbred groups differed in their heterotic performance on litter size traits, which was due to the nature and the degree of gene frequency differences between the parental lines, since heterosis is directly proportional to heterozygosity. The presence of these reciprocal cross differences will be useful in making decisions either to use the sire or dam of the superior strains in the improvement of litter size in pigs. The relatively low and negative heteroses for litter size traits at the backcross groups could suggest that the litter size traits of the base stocks used were mostly governed by additive and residual gene effects. This is consistent with the reports of Gunsett and Robinson, ${ }^{[3]}$ that heterosis for reproductive traits was low. The results in Table 7 indicated that most of the mainbackcross groups retained far less than $50 \%$ of the $F_{1}$ heterosis in the litter size traits studied. However, some of the reciprocal backcross groups showed higher percentage values of the $F_{1}$ heterosis in the traits. This means that, litter size traits heteroses of the main and reciprocal backcross groups were influenced by complete dominance of allelic genes and parental epistasis. Involving complimentary genes. This also agrees with the earlier reports of Sheridan ${ }^{[11]}$ and Haley et al.., ${ }^{[4]}$ that heterosis for litter size traits was variable but mostly influenced by dominance and epistatic gene effects.

Finally, it can be noted that impressive levels of heteroses for litter size traits were observed in the crosses between the native and exotic pigs, which were more in some groups especially the reciprocal crossbred groups) than in others. However, heterosis for litter size traits was low and mostly non significant. The heterosis recorded in the backcross groups were residual and higher in the main than the reciprocal backcross groups. It must also be noted that, the litter size traits performance in the native by exotic cross was influenced by maternal, sex - linked dominance and epistatic gene effects. This goes to emphasize that group trait selection involving the native and exotic backcrosses can be embarked upon to generate progenies which can be evaluated on litter size traits performance before criss crossing them for commercial stock.

\section{REFERENCES}

Adebambo, O.A. 1984 A Comparison of the indigenous and Exotic pure and crossbred sows in Southern Nigeria. Relationship between Dam and litter performance. Nigerian. Journal of Animal Production. 8:67- 74

Bidanal, J.P. 1993 Estimation of crossbreeding parameters between large White and Meishan reproductive traits. Genetics, Selection, Evolution $25263-281$

Gunsett, F.C. and Robinson, O.W. 1990 Crossbreeding effects on reproduction, growth and carcass traits. In: Young, L. D (ed) Genetics of Swine. NC- 103 Publication 57-72

Haley, C.S., Lee, G.J. and Ritchie, M. 1995 Comparative reproductive performance in Meishan and Large White Pigs and their crosses. Animal Science 61: $269-280$

Marire, B.N., Ugwu, S.O.C., Ogah, F. and Nwakpu, P.E.. 1997 Growth Characteristics of Local and Exotic boar under same management conditions. Nigeria Veterinary Journal, 18: $228-233$

Nwosu, C.C. 1987 Is the Local chicken essential or non essential? Invited Paper Poultry Farmers Workshop. Agric. Ext. and Res. Liason Service, A. B. U, Zaria, Nigeria Dec. 8 - 10. 13.

Nwakpu, P.E and Omeje, S.I.. 2004 Heterosis for body weight in native by Exotic inbred pig crosses. Journal of Science, Agriculture Food Technology and Environment, 4: 50 - 60 .

Omeje, S.I. 1989 Development of the Nigeria Chicken for improved production. A new approach. Invited paper. Agric Symp. Professors World Peace Academy, Ibadan, Nigeria. $18^{\text {th }}$ Dec. pp 8.

Olomu, J.M and Oboh, S.O. 1995.Pig production in Nigeria: Principles and Practices. A Jachem Publication, Nigeria. 186.

Sheridan, A.K. 1995 Crossbreeding and heterosis. Animal. Breed. Abstr. 1981 49(3): 131 - 144.

Sheridan, A.K. 1986. Selection for heterosis from crossbred population 1: Estimation of the F1 heterosis and it's made of inheritance. British Poultry Science. 27:541 550 .

Weiner, B.J. 1971.Statistical Principles in experimental design ( $2^{\text {nd }}$ ed.) McGraw Hill Ltd. Tokyo.

Williamson, G and Payne, W.J.A. 1992 An introduction to Animal Husbandry in the Tropics $\left(5^{\text {th }}\right.$ ed.) Longman, Inc. New York. 145 - 194.

Yule, G.U.and Kendall, M.G. 1968 An introduction to the theory of Statistics (14 ${ }^{\text {th }}$ ed) Charles Griffin and Co. Ltd, London. 